\title{
ПОНЯТТЯ КОРПОРАТИВНИХ ПРАВ ТА ÏХ ЗМІСТ: КОНЦЕПТУАЛЬНІ ОСНОВИ
}

\author{
ЛЕОНОВ К.Ю. - здобувач відділу проблем цивільного, трудового і \\ підприсмницького права, Інститут держави і права ім. В.М.Корецького НАН \\ України \\ УДК 347.122 \\ DOI 10.32782/LAW.UA.2021.2.24
}

У статті досліджуються основні конщептуальні підходи до з'ясування поняття корпоративних прав та їх змісту. Автор зазначає, що найбільш поширеними серед поглядів на правову природу корпоративних відносин $\epsilon$ підходи представників ицвілістичної доктрини, господарсъкого права, а також так званий комплексний підхід. Робиться висновок, що корпоративні права виникають лише $d$ окремих підприємницьких товариствах - товариств з обмеженою відповідальністю та акиіонерних товариств (капітал яких поділений на частки між учасниками). 3 огляду на специбічну правову природу корпоративних прав автор вважає їх особливим та самостійним об'єктом ичвільних правовідносин, щзо характеризується власними, не притаманними жодному іншому об'єктові ознаками. Забезпечення належного чивільного обороту таких об’єктів потребує внесення змін до чинного законодавства, у першу чергу - визнання їх як таких у числі об'єктів иивільних прав. Безперечно, такі зміни мають бути комплексними та спрямованими на удосконалення ичвільного обігу корпоративних прав між учасниками ициільних правовідносин.

Ключові слова. Корпоративні відносини, корпоративні права, иивільні правовідносини, юридична особа, господарсъке товариство, зміст корпоративних відносин.

\section{Постановка проблеми}

Одним з важливих шляхів до вирішення багатьох неузгодженостей у корпора- тивному законодавстві та практиці має стати сучасна правова доктрина корпоративних прав як об'єкта цивільних правовідносин. На підставі наукових методів дослідження необхідно напрацювати сучасне доктринальне розуміння поняття корпоративних прав, його змісту, структури, співвідношення та розмежування з іншими близькими правовими категоріями.

Вказана правова доктрина, виходячи 3 об’єктивних потреб суспільних відносин, повинна напрацьовувати рекомендації та пропозиції, спрямовані на вдосконалення вітчизняного корпоративного законодавства, усунення сучасних колізій та прогалин 3 метою якнайкращого захисту прав усіх учасників корпоративних правовідносин.

Аналіз останніх наукових досліджень і публікацій

Проаналізувавши дослідження із цієї тематики, можна визначити, що проблема доктринального розуміння поняття корпоративних прав, його змісту та структури, досі не вирішена, хоча певні аспекти у цьому напрямку розглядаються досить суттєво. Проблематика розкривається у працях таких науковців, як О.В. Долинська, О.Р. Кібенко, С.С. Кравченко,В.М. Кравчук, В.В. Ауць, І.В. СпасибоФатєєва, Р.Б. Сивий, О.І. Угриновська,О.С. Яворська та інші. Більшість термінів, використаних у цій роботі, $є$ результатом аналізу законодавства. 
Мета і завдання наукової статті - дослідити поняття корпоративних прав, їх ознаки та зміст, а також визначити можливі шляхи вирішення вказаної проблеми.

\section{Виклад основного матеріалу}

У наукових джерелах підходи до розуміння правової природи корпоративних відносин є неоднозначними. Незважаючи на значну кількість досліджень у цій сфеpi, науковці не дійшли до єдиного підходу стосовно тлумачення правової природи корпоративних прав. Грунтовне вивчення та аналіз цих питань на теоретичному рівні покликані сприяти не тільки подальшому розвитку наукових розробок, а й удосконаленню відповідної нормативно-правової бази.

Законодавче визначення корпоративних відносин міститься в ч. 3 ст. 167 ГК України. Цією нормою встановлено, що під корпоративними відносинами маються на увазі відносини, що виникають, змінюються та припиняються щодо корпоративних прав. Таке визначення не розкриває ні природи корпоративних прав, ні сутності корпоративних правовідносин; не наближають до такого розуміння й норми інших нормативно-правових актів [1].

Найбільш поширеними серед поглядів на правову природу корпоративних відносин $є$ підходи представників цивілістичної доктрини, господарського права, а також так званий комплексний підхід.

Згідно з першим підходом, або так званою «теорією цивільних правовідносин», корпоративні відносини $є$ предметом правового регулювання цивільного права. І.В. Спасибо-Фатєєва, обгрунтовуючи необхідність віднесення корпоративних відносин до цивільних, зазначає, що, оскільки корпоративні правовідносини є одним із видів цивільних правовідносин, їм притаманні всі ознаки цивільних правовідносин: дозволена спрямованість, захист суб'єктивних прав та майновий, компенсаційний характер відповідальності $[2$, с. 8].

Прихильники віднесення корпоративних відносин до цивільних виходять 3 того, що будь-який правовий зв'язок ви- являється у взаємності прав та обов'язків і притримуються позиції щодо доцільності віднесення корпоративних відносин до зобов'язальних, договірних, на підставі цих суджень вони приходять до висновку про цивільно-правовий характер таких відносин. Так, В. Ауць зазначає, що відносини, які складаються між учасником та юридичною особою мають зобов'язальну юридичну природу [3, с. 14].

Прихильники другого підходу до розуміння правової природи корпоративних прав обгрунтовують, що корпоративні відносини слід вважати різновидом господарських правовідносин (т.зв. теорія господарських правовідносин). Так,B.C. Щербина зазначає, що за своєю правовою природою корпоративні відносини $є$ поєднанням взаємопов'язаних і взаємообумовлених організаційно-господарських та майново-господарських відносин [4, с. 13]. Прихильники «господарсько-правового» підходу вважають, що в корпоративних відносинах нібито присутня наявність владного підпорядкування - а отже, відсутня юридична рівність у відносинах між суб'єктами корпоративних відносин, а також тим, що в багатьох випадках ці відносини можуть не містити майнових елементів.

Представники третього підходу притримуються поглядів про комплексний характер корпоративних відносин. Основна ідея такого підходу зводиться до того, що зміст корпоративного правовідношення становлять права та обов'язки різної галузевої приналежності: цивільні, адміністративні, фінансові, трудові тощо [5, с. 134].

I.C. Шиткіна зазначає, що корпоративні правовідносини становлять окрему групу врегульованих правом суспільних відносин, які не «вписуються» у традиційно існуючу класифікацію цивільно-правових відносин. Вона відзначає, що корпоративні правовідносини є комплексними правовідносинами, що становлять сукупність майнових і тісно пов'язаних з ними немайнових - організаційно-управлінських відносин [6, с. 31-55].

О. Р. Кібенко висловлюе позицію, згідно з якою все те, що так чи інакше 


\section{Цивільне, підприсмницьке, господарське та трудове право}

пов'язано 3 діяльністю господарських товариств, підпадає під регулювання норм корпоративного права. При цьому вона пропонує класифікувати корпоративні правовідносини на два види: внутрішні і зовнішні [7, с. 41-42].

Крім зазначених вище поглядів на правову природу корпоративних відносин, окремими науковцями висловлюються й альтернативні точки зору стосовно їх розуміння. Так, Г.А. Знаменський вважає, що цивільним правом можуть регулюватися лише особисті майнові відносини, а господарські майнові відносини належать до сфери регулювання господарського права. Цей висновок зроблено ним із посиланням на філологічне тлумачення, проведене у листопаді 2005 р. Інститутом української мови НАН України, який довів, що в ст. 1 ЦК України означення «особисті» стосується як немайнових, так і майнових відносин, тобто воно є спільним для обох типів відносин, які у статті названо уточненням «цивільні відносини». Також вказується, що значення прикметника «особистий» пов'язане 3 іменником «особа», «індивідуум». Тобто виходить, що існують не тільки особисті немайнові, а й особисті майнові відносини. I саме останні мають належати до цивільних прав [8, с. 177-178].

Однак, на наш погляд, не можна давати характеристику правовій природі будь-яких відносин і явищ, у тому числі й корпоративних відносин, за умов недосконалого правового регулювання, виходячи 3 буквального філологічного тлумачення окремих законодавчих конструкцій без зв'язку з їх доктринальним розумінням.

Варто погодитись 3 фахівцями, які зазначають, що корпоративні відносини мають складну правову природу та комплексний характер, що зумовлено недосконалістю вітчизняної законодавчої бази [9, c. 268].

Найбільш обгрунтованим 3 наведених є підхід, на наш погляд, згідно 3 яким корпоративні відносини слід відносини до цивільних правовідносин особливого виду, які мають риси як речових, так і зобов'язальних, а також свої специфічні особливості. Відносячи корпоративні від- носини до цивільних, необхідно оперувати, як слушно відзначає I.В. Спасибо-Фатєєва, методом регулювання: учасники завжди мають вибір щодо того, як їм поводитися. Підкорення ж виникає там і тоді, де і коли особи вибору не мають; корпорація не надає жодних наказів своїм учасникам, а останні не виступають підлеглими стосовно неї, бо самі формують її волю на загальних зборах; жодне з їх рішень не звужує можливостей учасника/акціонера i не паралізує його волю [10, с. 88].

У цілому, вбачається, що до корпоративних відносин доцільно відносити відносини між юридичною особою та їі учасниками, що виникають у процесі здійснення учасниками управління юридичною особою та реалізації майнових і немайнових прав та обов'язків. Останні грунтуються на праві участі в юридичній особі корпоративного типу - статутний капітал якої поділено на частки, учасники якої здійснюють управління юридичною особою та мають право на отримання частки від їі прибутків та інші права.

Отже, визначення корпоративних відносин нерозривно пов'язане і 3 визначенням кола юридичних осіб, щодо яких взагалі можна говорити про наявність корпоративних прав. На основі цих міркувань робиться висновок, що корпоративні права виникають лише в окремих підприємницьких товариствах - товариств 3 обмеженою відповідальністю та акціонерних товариств (капітал яких поділений на частки між учасниками).

Законодавство не містить вичерпної відповіді з цього питання. У свою чергу, судова практика притримується широкого підходу до розуміння кола юридичних осіб, у яких можливими 6 корпоративні відносини. Так, у постанові Пленуму Вищого господарського суду «Про деякі питання практики вирішення спорів, що виникають 3 корпоративних правовідносин» від 25 лютого 2016 року № 4 вказується, що корпоративні відносини виникають, зокрема, у господарських товариствах, виробничих кооперативах, фермерських господарствах, приватних підприємствах, 
заснованих на власності двох або більше осіб [11].

У силу невизначеності норм законодавства у частині висвітлення суті корпоративних відносин, слід уточнити, що такі відносини можуть мати місце лише у юридичних особах корпоративного типу, статутний капітал яких поділений на частки, а законодавство передбачає можливості участі таких учасників в управлінні юридичною особою, отримання частини прибутку від їі діяльності та реалізації інших корпоративних прав та обов'язків.

Дослідження правової природи корпоративних відносин вимагає й визначення їх структури, до якої традиційно відносяться об'єкт, суб'єкт та зміст. Згідно із загальноприйнятим у цивілістиці підходом, об'єктом правовідносин, як вказувалося вище, слід вважати блага, з приводу яких суб'єкти вступають у ті чи інші правовідносини. Виходячи 3 таких засад, на наш погляд, варто погодитися з позицією, згідно 3 якою об'єктом корпоративних правовідносин є участь у юридичній особі.

Як зазначає В.М. Кравчук, участь - це правовий зв'язок між товариством та його учасником, який полягає у взаємних майнових та немайнових правах та обов'язках 3 приводу задоволення учасниками своїх законних інтересів унаслідок діяльності товариства. Майнова участь у товаристві, на його думку - це участь у капіталі, яка виявляється у праві на частку в статутному капіталі (акцію), на одержання частини прибутку або частини іiі майна у разі ліквідації та інших майнових корпоративних правах; немайнова участь у товаристві це участь особи в діяльності товариства (участь у справах), унаслідок чого в неї виникає право на участь в управлінні (право голосу) та інші організаційні корпоративні права; змішана участь передбачає одночасно майнову та немайнову участь. Участь у господарських товариствах є змішаною або майновою, у непідприємницьких товариствах - немайновою [12].

Суб'єктами корпоративних правовідносин є юридична особа та її учасники (засновники, члени, акціонери тощо). Відносини між цими суб'єктами виникають на підставі та регулюються нормами цивільно-правового договору (на етапі заснування юридичної особи), нормами установчих документів юридичної особи та нормативно-правових актів.

Змістом корпоративних правовідносин є взаємні права та обов'язки юридичної особи корпоративного типу та їі засновників (учасників) [12]. 3 огляду на традиційний підхід виокремлення зі змісту правовідносин матеріального та вольового, під матеріальним змістом корпоративних правовідносин слід розуміти фактичну поведінку їх учасників 3 приводу здійснення ними майнових та особистих немайнових прав.

Вольовий зміст корпоративних правовідносин появляється у взаємодії волі законодавця, висловленої у правових нормах, що регулюють корпоративні правовідносини, та особистої волі учасників цих відносин, вираженої у локальних корпоративних нормах і діях учасників.

Таким чином, можна зробити висновок, що в структурі корпоративних відносин корпоративним правам належить роль змісту таких правовідносин. Попри це, такий висновок жодним чином не заперечує того, що одночасно такі права можуть виступати об'єктом інших цивільних правовідносин. Аналіз природи корпоративних прав має сприяти визначенню характеристик такого об'єкта цивільних правовідносин і виокремленню особливостей їх оборотоздатності.

Законодавча дефініція поняття корпоративних прав наводиться уч. 1 ст. 167 ГК України, яка визначає їх як права особи, частка якої визначається у статутному капіталі (майні) господарської організації, що включають правомочності на участь цієї особи в управлінні господарською організацією, отримання певної частки прибутку (дивідендів) цієї організації та активів у разі ліквідації останньої відповідно до закону, а також інші правомочності, передбачені законом та статутними документами [1]. Володіння корпоративними правами не вважається підприємництвом. Законом можуть бути встановлені обмеження певним особам щодо володіння 


\section{Цивільне, підприємницьке, господарське та трудове право}

корпоративними правами та/або їх здійснення. У ст. 14 ПК України теж містить аналогічне визначення корпоративних прав [13]. Однак, у чинному законодавстві України відсутні норми, які б надавали корпоративних правам значення самостійного об'єкта цивільних правовідносин та визначали умови їх оборотоздатності.

Загалом, у юридичній літературі корпоративне право прийнято розглядати в кількох значеннях - об'єктивному та суб'єктивному.

Найбільш поширеними $є$ наступні визначення корпоративного права. Корпоративне право в об'єктивному значенні це сукупність правових норм, які регулюють і охороняють цивільні і інші відносини, що виникають між акціонером і самою корпорацією, а також між самими учасниками чи акціонерами з приводу реалізації їх права власності на акцію чи права власності на частку в статутному фонді корпорації. Розкриваючи значення корпоративного права в об'єктивному розумінні, його також називають галуззю, що перебуває в динамічному русі, це обумовлено створенням нових та розширенням уже сучасних ринків, які часто поширюються на країни, правове регулювання яких є різним. Зазначене також сприяє постійній модифікації цих відносин [14, с. 20].

Сучасні дослідження вітчизняних науковців дозволяють зробити висновок про можливість виокремлення трьох основних концепцій, які характеризують правову природу корпоративних прав. Представники першої концепції обгрунтовують речово-правову природу корпоративних прав. Частина вчених відстоюють зобов'язально-правову природу корпоративних прав [3, с. 14]. Представники третьої групи вчених притримуються іншої концепції, у межах якої обгрунтовують специфічний характер корпоративних відносин та відводять їм окреме місце в предметі цивільно-правового регулювання поряд з речовими та зобов'язальними відносинами [15, с. 23-38].

На переконливу думку В.М. Кравчука, корпоративні права - це сукупність прав учасника юридичної особи, зміст яких визначається їі організаційно-правовою формою та установчими документами. Конкретний склад корпоративних прав, на думку вченого, залежить від виду участі і визначається організаційно-правовою формою юридичної особи. Між організаційними i майновими корпоративними правами є певна взаємозалежність: у випадку обмеження організаційних прав особа одержує певні переваги у реалізації майнових прав [12, с. 11].

C.B. Томчишен зазначає, що, 3 одного боку, корпоративне право $є$ самостійним правом, яке містить ряд правомочностей його володільця щодо юридичної особи (господарської організації), учасником якої він є. 3 другого боку, він відзначає, що відчуження володільцем корпоративного права своєї частки фактично спричиняє перехід й усіх інших правомочностей, тобто корпоративного права в цілому [16, с. 15]. Виходячи з такого підходу, визначення частки вважається лише засобом закріплення за особою корпоративних прав. О.В. Долинська вважає, що корпоративні права, які є елементом корпоративних відносин, за своїм змістом близькі до зобов’ язальних [17, с. 192].

Визнаючи цивільно-правову природу корпоративних прав, неможливо однозначно віднести їх до речових або до зобов'язальних прав. Так, корпоративне право засноване на участі особи в юридичній особі корпоративного типу включає в себе комплекс правомочностей майнового (наприклад, право на отримання частини прибутку) та немайнового характеру (право на отримання інформації про діяльність юридичної особи). Частина 3 них за своєю природою мають одночасно риси речових та зобов'язальних, наприклад, право участі у юридичній особі, формалізоване у вигляді частки у статутному капіталі. У зв'язку $з$ цим вбачається, що учасником юридичної особи одночасно закріплюється можливість безпосереднього впливу на це своє право, наприклад, він має право здійснити його відчуження за дотримання необхідних умов.

3 іншого боку, право на участь у товаристві має риси й зобов'язальних прав. 
Зокрема, учасник, на підставі наявності у ньому такого права, у праві вимагати від юридичної особи вчинення певних дій (провести загальні збори тощо). Разом 3 цим, до корпоративного права входять правомочності як майнового, так і немайнового характеру. Підтвердженням цього слугує й ч. 1 ст. 100 ЦК України, відповідно до якої право участі у товаристві є особистим немайновим правом і не може окремо передаватися іншій особі. Таким чином, передавати права участі в товаристві іншій особі можна лише окремо, а разом 3 іншими майновими правами право участі у товаристві може передаватися у порядку, що встановлений законом та установчими документами. Ця обставина додаткового свідчить про комплексний характер корпоративних прав та неможливість їх віднесення тільки до майнових або немайнових.

Попри нормативну визначеність, що корпоративні права можуть бути майновими та немайновими, не всі науковці 3 цим погоджуються. Так, деякі вчені вважають, що оскільки здійснення корпоративних прав має на меті задоволення майнових інтересів їх носіїв, вони пов’язані 3 майновою участю засновника у створенні юридичної особи, то їх слід відносити до числа майнових [18]. Прихильники такого підходу зазначають, що вкладення капіталу учасником господарського товариства, його примноження та одержання прибутку з вкладеного капіталу складає головний інтерес учасника товариства, для захисту якого законодавством закріплені права учасника (акціонера). На підставі цього робиться висновок, що права учасників (акціонерів) завжди мають майновий характер [17, с. 192].

3 такою точкою зору погодитися не можна, оскільки мета діяльності учасника цивільних правовідносин - комерційна чи некомерційна, отримання матеріальних вигод чи немайнових благ не означає, що й усі права, якими наділений учасник таких відносин, також є відповідно майновими/немайновими.

Отже, переконливою вбачається позиція, згідно 3 якою корпоративні права $\epsilon$ як майновими, так і немайновими, i їх немайнова частина не може відчужуватися іншій особі окремо від майнової. При цьому, корпоративне право має два складові елементи: управлінський та майновий [19, c. 38].

Вважаємо доречною й думку вчених, які відзначають таку особливість корпоративних прав як їхню можливість проявляти в тих чи інших правовідносинах лише якусь одну свою властивість: у певних правовідносинах проявляються тільки як майнові, а в певних - навпаки, тільки як немайнові права. При цьому у зовнішніх правовідносинах корпоративні права втрачають свою подвійну правову природу та є певною єдністю як об'єкт права [20, с. 10]. Наведене додатково свідчить про те, що у складі корпоративних прав наявні більш дрібні складові (або правомочності), з яких вони складаються. Це право на участь в управлінні товариством, право на одержання певної частки прибутку (дивідендів) товариства та активів у разі його ліквідації, інші правомочності, передбачені законом та установчими документами. Кожне 3 них має самостійні етапи та форми здійснення, охорони та захисту, проте це не надає їм автономності повною мірою, щоб вони стали самостійними суб'єктивними правами [20, с. 10].

\section{Висновки}

На основі викладеного, можна виокремити такі суттеві ознаки корпоративних прав: вони становлять собою зміст корпоративних правовідносин та одночасно об'єктом інших цивільних правовідносин, які не є корпоративними; є комплексним об'єктом цивільних правовідносин, що містить сукупність правомочностей як майнового, так і немайнового характеру; не відносяться окремо ні до речових, ні до зобов'язаних прав, а мають специфічну правову природу, якій притаманні ознаки обох названих категорій; можуть відчужуватися лише комплексно, відчуження окремих складових корпоративного права не допускається; частка у статутному капіталі (акція) є лише зовнішнім спосо- 


\section{Цивільне, підприсмницьке, господарське та трудове право}

бом оформлення (фіксації) корпоративних прав, засобом їх оборотоздатності.

3 огляду на специфічну правову природу корпоративних прав останні слід вважати особливим та самостійним об'єктом цивільних правовідносин, що характеризується власними, не притаманними жодному іншому об'єктові ознаками. Забезпечення належного цивільного обороту таких об’єктів потребує внесення змін до чинного законодавства, у першу чергу визнання їх як таких у числі об'єктів цивільних прав. Безперечно, такі зміни мають бути комплексними та спрямованими на удосконалення цивільного обігу корпоративних прав між учасниками цивільних правовідносин.

Виходячи $з$ наведеного, пропонується законодавчо ввести дефініцію корпоративних прав, виклавши ії таким чином: корпоративні права - це об'єкт цивільних правовідносин, що є сукупністю прав особи, частка якої визначається у статутному капіталі (майні) господарської організації, що включають правомочності на участь цієї особи в управлінні господарською організацією, отримання певної частки прибутку (дивідендів) цієї організації та активів у разі ліквідації останньої відповідно до закону, а також інші правомочності, передбачені законом та статутними документами.

При цьому ст. 167 ГК України, яка містить визначення корпоративних прав, доцільно доповнити пунктом наступного змісту: «Відчуження корпоративних прав здійснюється шляхом відчуження часток у статутному капіталі (майні) господарської організації. Перехід права на частку у статутному капіталі (майні) господарської організації означає перехід до набувача частки всіх правомочностей, що входять до корпоративних прав».

\section{Література}

1. Господарський кодекс України від 16.01. 2003 р. База даних «Законодавство України». URL: https://zakon.rada.gov.ua/ laws/show/436-15\#Text.
2. Спасибо-Фатєєва І.В. Цивільно-правові проблеми акціонерних правовідносин. Х., 2000. 36 с.

3. Ауць В. В., Сивий Р. Б., Яворська О. С. Акціонерне право : навч. посіб. / за заг. ред. В. В. Ауця, О. Д. Крупчана. К., 2004. $256 \mathrm{c}$.

4. Щербина В. Правова природа корпоративних відносин. Українське комерційне право. 2006. № 7. С.10-14.

5. Гаранонич О.В. Правова природа корпоративних відносин між акціонером та акціонерним товариством. Часопис цивільного і кримінального судочинства. 2016. № 3(30). C.130-141.

6. Корпоративное право: учебный курс: учеб. / отв. ред. И. С. Шиткина. М.: КНОРУС, 2011. $1120 \mathrm{c}$.

7. Кибенко Е.Р. Корпоративное право. Учебное пособие. Харьков: Эспада, 1999. $480 \mathrm{c}$.

8. Кравченко C.С. Правова природа корпоративних прав. Часопис Київського університету права. 2010/2. С. 176-179.

9. Симонян Ю.Ю. Правова природа корпоративних відносин. Актуальні проблеми держави і права. 2008. Вип. 38. C.268-272.

10. Спасибо-Фатєева І.В. Вчення про корпоративні права і цивілістична доктрина. Право України. 2014. № 6. С.84-92.

11. Про деякі питання практики вирішення спорів, що виникають 3 корпоративних правовідносин: Постанова Пленуму Вищого господарського суду України № 4 від 25 лютого 2016 р. База даних «Законодавство України». URL: https://zakon. rada.gov.ua/laws/show/v0004600-16\#Text.

12. Кравчук В.М. Припинення корпоративних правовідносин в господарських товариствах: автореф. дис. ... канд. юрид. наук: 12.00.03. X., 2010.38 c.

13. Податковий кодекс України від 2.12. 2010 р. База даних «Законодавство України». URL: https://zakon.rada.gov.ua/ laws/show/2755-17\#Text.

14. Бородовський С.О. Корпоративні відносини як предмет цивільного права України. Актуальні питання цивільного та господарського права України. 2006. №1. C.19-22. 
15. Спасибо-Фатеева

И.В.

Акционерные общества: корпоративные правоотношения. Харьков: Право, 1998. $256 \mathrm{c}$.

16. Томчишен С.B. Корпоративні права як об'єкт цивільних прав у законодавстві України. Актуальні питання цивільного та господарського права. 2008. №1. C.9-17.

17. Долинська О.В. Юридична природа корпоративних прав учасників господарських товариств. Університетські науков записки. 2008. №4 (28). С. 190-194.

18. Гражданское право. В 4-х томах. Том 1: Общая часть.: отв. ред. Е. А. Суханов. 3-е изд., перераб и доп. М.: Волтерс Клувер, 2006. 720 с.

19. Угриновська О.І. Проблеми виконання рішень 3 корпоративних правовідносин. Захист корпоративних прав інвесторів в світлі нового Цивільного кодексу України : матеріали семінару, (16-18 квіт. 2003 р.). Аьвів : Юрид. $\Phi$-т Аьвів. нац. унту ім. I. Франка, 2003. С. 38-41.

20. Кравченко С.С. Юридична природа прав учасників господарських товариств: автореф. дис. ... канд. юрид. наук: 12.00.03. K., 2007. 18 c.

SUMMARY
The article explores the main conceptual ap-
proaches to clarifying the concept of corporate
rights and their content. The author notes that the
most common views on the legal nature of corpo-
rate relations are the approaches of the representa-
tives of civil doctrine, commercial law, as well as
the so-called integrated approach. It is concluded
that corporate rights arise only in certain business
companies - limited liability companies and joint
stock companies (the capital of which is divided into
shares between the participants). Taking into ac-
count the specific legal nature of corporate rights,
the author considers them to be a special and inde-
pendent object of civil legal relations that is char-
acterized by its own features, not inherent in any
other object. Ensuring the proper civil circulation
of such objects requires amendments to the current
legislation, first of all - recognition of them as such
among the objects of civil rights. Undoubtedly, such
changes should be comprehensive and aimed at im-
proving the civil circulation of corporate rights be-
tween the participants in civil legal relations.
Key words. The corporate relations, the corpo-
rate rights, the civil legal relations, the legal entity,
the business association, the content of corporate
relations.

